\title{
SINTESIS, KARAKTERISASI, DAN UJI AKTIFITAS FOTOKATALITIK NANOPARTIKEL MAGNETIK TiO ${ }_{2}-\mathrm{CoFe}_{2} \mathrm{O}_{4}$
}

\author{
Rahmayeni, Upita Septiani, Syukri Arief, Hayatul Hamdi \\ Jurusan Kimia FMIPA Universitas Andalas \\ Email: rahmayenni83@yahoo.com
}

\begin{abstract}
Magnetic nanoparticles of $\mathrm{TiO}_{2}-\mathrm{CoFe}_{2} \mathrm{O}_{4}$ were prepared using metal nitric and tiatniumisopropoxide as starting materials by coprecipitation and hydrolysis method. XRD, SEM, EDX and VSM were used to characterize the structure, morphology, composition and magnetic property of the particles, respectively. XRD pattern show the diffraction peaks of $\mathrm{TiO}_{2}$ anatase at $2 \theta=25.3^{\circ}$ and $\mathrm{CoFe}_{2} \mathrm{O}_{4}$ at $2 \theta=35.5^{\circ}$ in $\mathrm{TiO}_{2}-\mathrm{CoFe}_{2} \mathrm{O}_{4}$ particles. SEM image show the regular morphology and size distribution of particles. From VSM analysis indicate that the particles have paramagnetic properties. Photocatalytic activities of particles were applied for degradation of rhodamin $\mathrm{B}$ and the results showed that $\mathrm{CoFe}_{2} \mathrm{O}_{4}$ doped into $\mathrm{TiO}_{2}$ can increase the activities of particles in visible light until $82 \%$.
\end{abstract}

Key words : nanopartikel magnetik, $\mathrm{TiO}_{2}-\mathrm{CoFe}_{2} \mathrm{O}_{4}$, fotokatalis

\section{PENDAHULUAN}

Fotokatalis semikonduktor $\mathrm{TiO}_{2}$ telah menarik perhatian para peneliti karena kemampuannya dalam mendegradasi senyawa-senyawa organik berbahaya, yang terdapat dalam air limbah yang berasal dari industri-industri dan rumah tangga. Beberapa alasan yang menyebabkan $\mathrm{TiO}_{2}$ menjadi fotokatalis yang sering digunakan antara lain stabilitas kimianya yang baik, tidak beracun, murah, banyak terdapat di alam, dan tidak korosif. Reaksi fotokatalitik yang terjadi pada permukaan $\mathrm{TiO}_{2}$ menjadi faktor penting yang menentukan kinetika dan mekanisme reaksi fotokatalitik. Aktivitas katalitik $\mathrm{TiO}_{2}$ dipengaruhi oleh struktur kristal, luas permukaan, distribusi ukuran partikel, porositas dan permukaan. $\mathrm{TiO}_{2}$ murni dengan struktur kristal anatase yang metastabil mempunyai band gap yang lebar $(3,2 \mathrm{eV})$ telah menjadikannya sebagai fotokatalis diaktivasi oleh UV yang dominan digunakan ${ }^{[1-4]}$.

Ketergantungan pada sistim fotokatalitik yang diaktifkan oleh cahaya tampak meningkat dengan cepat. Pada saat ini sangat terbatas fotokatalis yang efesien, mudah didapatkan dan dengan mudah dapat diaktifkan secara efektif oleh cahaya matahari dan cahaya penerangan rumah. Polusi lingkungan terutama perairan dalam skala global merupakan masalah yang cukup besar yang harus dipecahkan oleh ahli kimia. Hal ini mendorong sejumlah ahli kimia dalam mencari sistim fotokatalitik baru untuk cairan. Pada umumnya sistim fotokatalitik yang digunakan saat ini adalah $\mathrm{TiO}_{2}$ murni atau yang dimodifikasi dengan struktur kristal anatase yang metastabil dengan band gap yang lebar untuk fasa anatase, akan tetapi sistim fotokatalitik ini mempunyai kelemahan yaitu efesiensi fotokatalitiknya yang rendah dan hanya $3-5 \%$ spektrum cahaya matahari yang dapat diserap. Untuk mengatasi masalah ini para peneliti telah melakukan sejumlah strategi utuk memodifikasi $\mathrm{TiO}_{2}$ meliputi kontrol terhadap morfologi dan fasa, pendopingan, koupling semikonduktor dan lain-lain ${ }^{[4,5]}$.

Kebanyakan teknik yang berhasil digunakan untuk modifikasi $\mathrm{TiO}_{2}$ sebagai fotokatalis pada sinar tampak adalah metode implantasi ion menggunakan ion $\mathrm{Cr}$ atau $\mathrm{V}^{[6,7]}$, berbagai teknik sintesis[8], dan substitutional doping dari nonlogam seperti $\mathrm{N}\left(\mathrm{TiO}_{2-\mathrm{x}} \mathrm{N}_{\mathrm{x}}\right)^{[8,9]}$. Selain 
itu, modifikasi $\mathrm{TiO}_{2}$ juga bisa dilakukan dengan substitusional doping dari oksida logam, salah satunya untuk mensintesis $\mathrm{TiO}_{2}$ $\mathrm{MFe}_{2} \mathrm{O}_{4}$ menggunakan metode fasa gas, pengendapan (kopresipitasi), hidrotermal, mikroelusi, sol-gel, sonochemistry, hidrolisis dan high energy ball milling ${ }^{[10]}$.

Nanopartikel $\mathrm{MFe}_{2} \mathrm{O}_{4}(\mathrm{M}=$ logam transisi $)$ seperti $\mathrm{ZnFe}_{2} \mathrm{O}_{4}$ yang bersifat magnit dapat digunakan sebagai partikel yang dapat meningkatkan efek fotokatalitik $\mathrm{TiO}_{2}$ karena mempunyai bandgap yang lebih sempit dibandingkan $\mathrm{TiO}_{2}$ [11]. Penambahan $\mathrm{MFe}_{2} \mathrm{O}_{4}$ ke dalam $\mathrm{TiO}_{2}$ dengan perbandingan tertentu akan meningkatkan fotorespon dan aktifitas fotokatalitik $\mathrm{TiO}_{2}$ pada daerah sinar tampak sehingga dapat digunakan sebagai katalis untuk senyawa-senyawa organik dalam air dengan adanya sinar UV dan tampak dari cahaya matahari. Selain itu material yang dihasilkan mempunyai sifat magnet yang sangat berguna dalam proses daur ulang sehingga lebih hemat ${ }^{[4,11]}$. Pada penelitian ini dilakukan pembuatan nanopartikel $\mathrm{TiO}_{2}-$ $\mathrm{CoFe}_{2} \mathrm{O}_{4}$ menggunakan metode kopresipitasi dan hidrolisis kemudian dikarakterisasi dengan SEM-EDX, XRD, dan VSM yang tujuannya untuk mempelajari struktur dan sifat dari nanopartikel tersebut. Aktifitas fotokatalitik partikel $\mathrm{TiO}_{2}-\mathrm{CoFe}_{2} \mathrm{O}_{4}$ diuji terhadap fotodegradasi senyawa rodamin $\mathrm{B}$ pada daerah sinar tampak (cahaya matahari).

\section{METODOLOGI PENELITIAN}

Bahan. Bahan-bahan yang digunakan antara lain: Titanium Isopropoksida 97\% (SigmaAldrich), $\quad \mathrm{Co}\left(\mathrm{NO}_{3}\right)_{2} \cdot 6 \mathrm{H}_{2} \mathrm{O} \quad 98 \%$ (Merck), $\mathrm{Cu}\left(\mathrm{NO}_{3}\right)_{2} .3 \mathrm{H}_{2} \mathrm{O} 98 \%$ (Merck), $\mathrm{Fe}\left(\mathrm{NO}_{3}\right)_{3} .9 \mathrm{H}_{2} \mathrm{O}$ 98\% (Merck), etanol p.a, 1-propanol p.a, isopropanol p.a, akuades, amonia dan rhodamin $\mathrm{B}$.

\section{Pembuatan nanopartikel $\mathrm{TiO}_{2}-\mathrm{CoFe}_{2} \mathrm{O}_{4}$}

$\mathrm{TiO}_{2}-\mathrm{CoFe}_{2} \mathrm{O}_{4}$ dibuat melalui prosedur sebagai berikut; $\mathrm{Fe}\left(\mathrm{NO}_{3}\right)_{3} \cdot 9 \mathrm{H}_{2} \mathrm{O}$ dan $\mathrm{Co}\left(\mathrm{NO}_{3}\right)_{2} \cdot 6 \mathrm{H}_{2} \mathrm{O}$ dilarutkan dalam alkohol sehingga diperoleh larutan garam nitrat dengan konsentrasi 0,5 M. Larutan $\mathrm{Fe}$ nitrat dan $\mathrm{Co}$ nitrat dicampur dengan perbandingan mol $\mathrm{Fe}: \mathrm{Co}=2: 1$. Campuran tersebut dipanaskan pada temperatur $65{ }^{\circ} \mathrm{C}$ dengan proses stirrer yang tetap selama 30 menit. Kemudian, $\mathrm{pH}$ campuran dinaikkan menjadi 6,5 dengan penambahan $\mathrm{NH}_{4} \mathrm{OH}$ dalam alkohol, dilanjutkan dengan penambahan $10 \mathrm{~mL}$ akuades dan distirer kembali selama 45 menit. Setelah itu, ditambahkan larutan TIP dalam alkohol dengan perbandingan 1 : 2. Larutan TIP/alkohol ditambahkan setetes demi setetes ke dalam campuran dan distirer lagi pada suhu $65{ }^{\circ} \mathrm{C}$ selama 90 menit. Campuran dioven pada temperatur $120{ }^{\circ} \mathrm{C}$ dan dikalsinasi dengan variasi temperatur selama 3 jam.

\section{Uji Aktifitas Fotokatalitik Nanopartikel $\mathrm{TiO}_{2}-\mathrm{CoFe}_{2} \mathrm{O}_{4}$}

Rhodamin B ditimbang sebanyak 0,005 g, dilarutkan dengan akuades dalam labu 1000 $\mathrm{mL}$ dan didapatkan konsentrasi larutan $5 \mathrm{ppm}$. Larutan tersebut diambil $20 \mathrm{~mL}$ dan ditambahkan 0,02 g nanopartikel $\mathrm{TiO}_{2}-$ $\mathrm{CoFe}_{2} \mathrm{O}_{4}$. Campuran tersebut kemudian disinari di bawah sinar matahari dengan variasi lama waktu penyinaran $0,60,120$ dan 180 menit. Setelah dilakukan penyinaran, campuran disentrifus dan diukur serapan larutan dengan menggunakan spektrofotometer UV-Vis untuk mengetahui banyaknya rhodamin B yang terdegradasi.

\section{HASIL DAN DISKUSI}

\section{Karakterisasi dengan $X$-ray Diffraction (XRD)}

Analisis XRD dilakukan untuk mengetahui struktur dan ukuran kristal $^{12}$. Dari analisis XRD (XRD Philips PW 1710, XRD XD-610) ini akan dapat diketahui pengaruh temperatur kalsinasi dan konsentrasi ion dopan terhadap perubahan struktur titania dari anatase ke rutil. Hal ini dapat diamati dari pola XRD dari nanopartikel $\mathrm{TiO}_{2}-\mathrm{CoFe}_{2} \mathrm{O}_{4}$ pada Gambar 1 dan 2. 


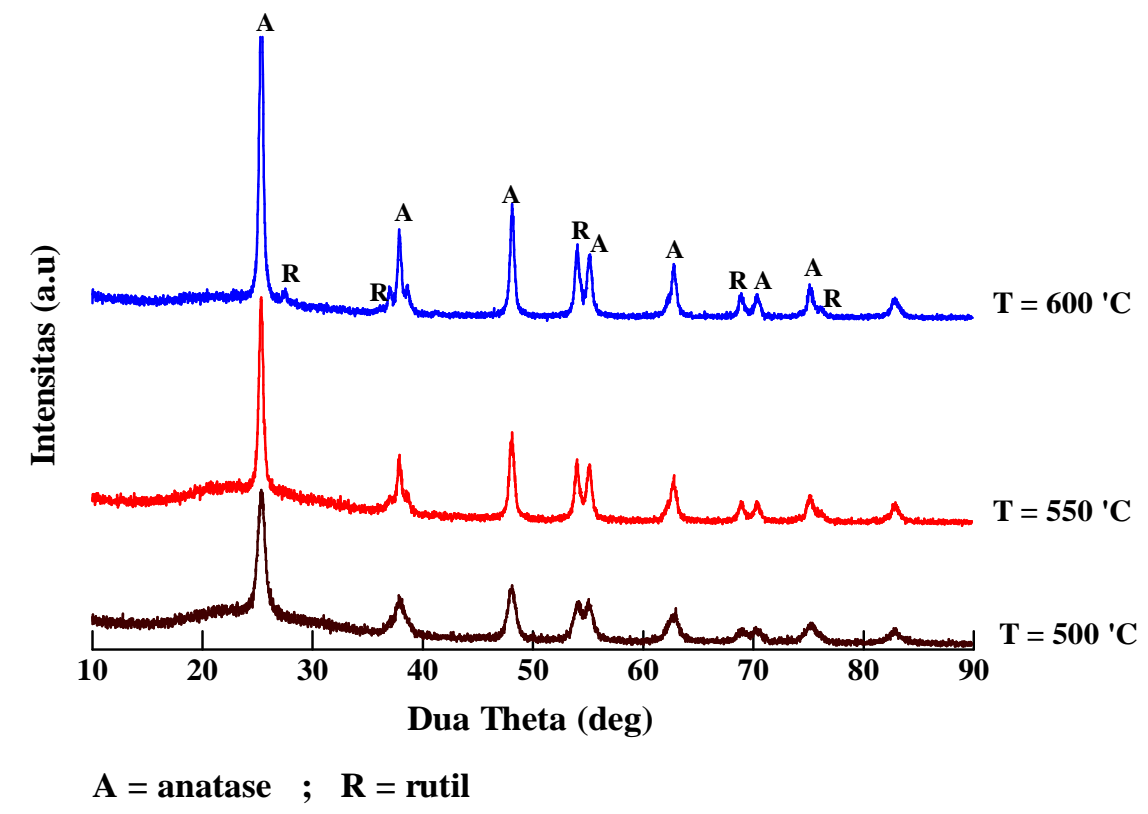

Gambar 1. Spektrum XRD nanopartikel $\mathrm{TiO}_{2}-\mathrm{CoFe}_{2} \mathrm{O}_{4}$ dengan konsentrasi ion dopan 0,01 menggunakan variasi temperatur kalsinasi

Gambar 1 memperlihatkan pola XRD dari $\mathrm{TiO}_{2}-\mathrm{CoFe}_{2} \mathrm{O}_{4}$ dengan variasi temperatur kalsinasi, $500{ }^{\circ} \mathrm{C}, 550{ }^{\circ} \mathrm{C}$ dan $600{ }^{\circ} \mathrm{C}$. Dari pola XRD pada temperatur $500{ }^{\circ} \mathrm{C}$ dapat dilihat munculnya puncak tertinggi pada sudut 20: $25.3^{\circ}$ yang mengindikasikan puncak dari titania fase anatase. Pada temperatur kalsinasi $550{ }^{\circ} \mathrm{C}$ juga muncul puncak tertinggi pada sudut $2 \theta=25.3^{\circ}$ namun dengan intensitas yang lebih tinggi dan mulai muncul puncak rutil. Kemudian pada temperatur $600{ }^{\circ} \mathrm{C}$, disamping muncul puncak pada $2 \theta=25.3^{\circ}$, juga terdapat puncak pada $2 \theta=27.5^{\circ}$ yang mengindikasikan terdapatnya titania fase rutil. Dengan demikian, semakin tinggi temperatur kalsinasi akan merubah titania dari fase anatase ke rutil. Ukuran kristal dapat dihitung dengan menggunakan persamaan Debye-Schereer. Dari ketiga spektrum XRD pada Gambar 1 diperoleh ukuran kristal nanopartikel pada temperatur kalsinasi 500, 550, dan $600{ }^{\circ} \mathrm{C}$ sebesar $8,73 \mathrm{~nm}, 12,08 \mathrm{~nm}$ dan $15,71 \mathrm{~nm}$ berturut-turut. Dari ukuran kristal yang diperoleh dapat disimpulkan bahwa peningkatan temperatur kalsinasi dapat meningkatkan ukuran kristal.

Gambar 2 memperlihatkan pola XRD dari $\mathrm{CoFe}_{2} \mathrm{O}_{4}$ dan $\mathrm{TiO}_{2}-\mathrm{CoFe}_{2} \mathrm{O}_{4}$ dengan perbandingan $\mathrm{TiO}_{2}: \mathrm{CoFe}_{2} \mathrm{O}_{4}(1: \mathrm{X})$ dengan $\mathrm{X}$ $=0,01 ; 0,1$ dan 0,3 . Pada pola XRD muncul puncak tertinggi pada sudut $2 \theta=25.3^{\circ}$ yang mengindikasikan fase anatase dari titania. Untuk pola XRD pada $X=0,1$ dan 0,3 muncul puncak pada sudut $2 \theta=35.5^{\circ}$ dan $62,1^{\circ}$ yang diperkirakan puncak dari $\mathrm{CoFe}_{2} \mathrm{O}_{4}$. Hal ini mengindikasikan telah terdopingnya $\mathrm{CoFe}_{2} \mathrm{O}_{4}$ pada $\mathrm{TiO}_{2}$. Selain itu, pada konsentrasi oksida logam yang lebih tinggi didapatkan titania sebagai campuran fase anatase dan rutil. Hal ini dapat dilihat dari munculnya puncak pada sudut $2 \theta=27.5^{\circ}$ dan sudut lainnya yang mengindikasikan fase rutil dari titania. 


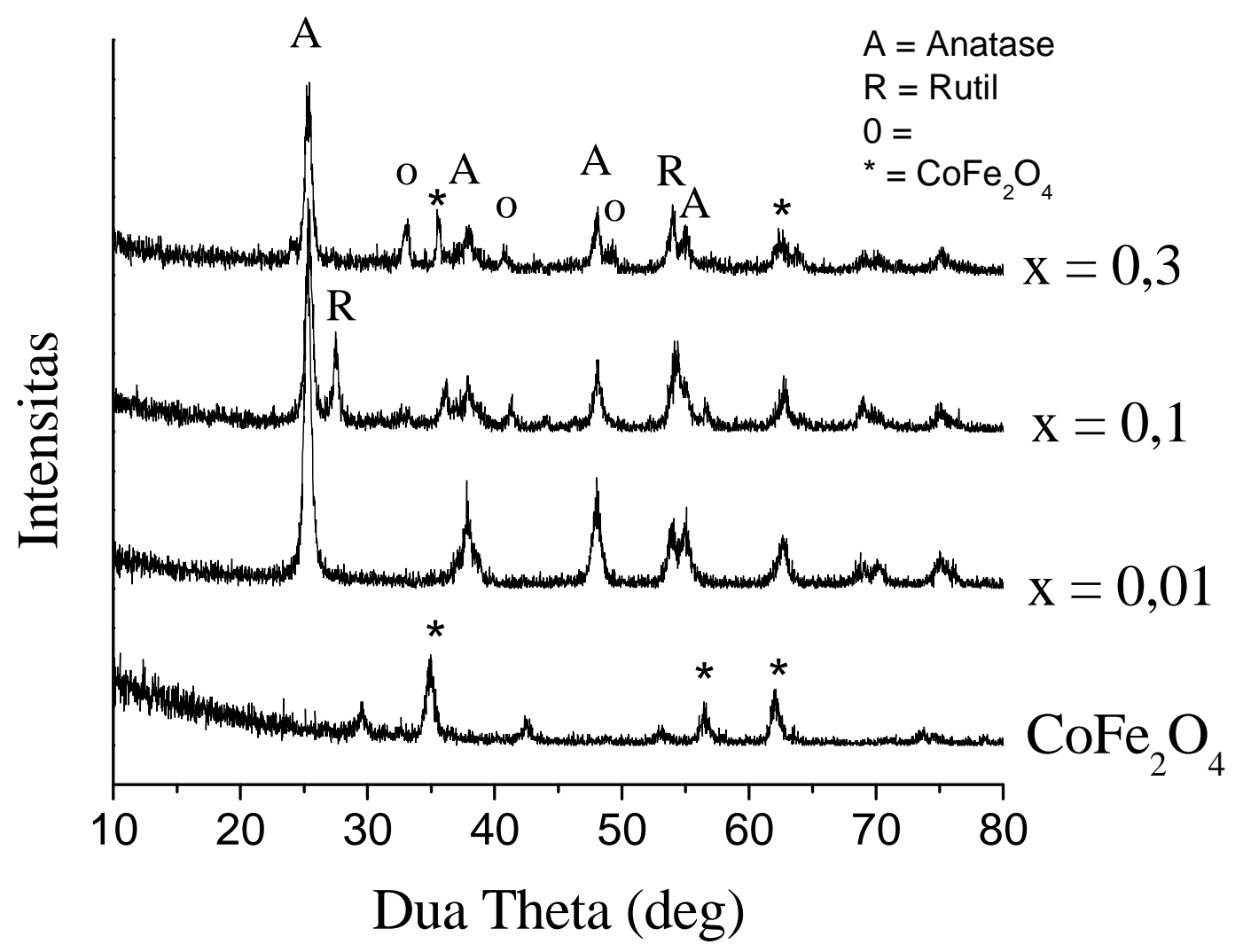

Gambar 1. Pola XRD nanopartikel $\mathrm{CoFe}_{2} \mathrm{O}_{4}$ dan $\mathrm{TiO}_{2}-\mathrm{CoFe}_{2} \mathrm{O}_{4}$ dengan berbagai konsentrasi oksida logam $\mathrm{CoFe}_{2} \mathrm{O}_{4}$

\section{Scanning Electron Microscopy - Energy Dispersive X-ray (SEM - EDX)}

Gambar 3 memperlihatkan foto SEM (SEM JEOL JSM-6360LA) dari nanopartikel $\mathrm{TiO}_{2}$ $\mathrm{CoFe}_{2} \mathrm{O}_{4}$ dengan konsentrasi ion dopant 0,01 yang dikalsinasi pada temperatur $500^{\circ} \mathrm{C}$. Dari gambar ini dapat diamati permukaan nanopartikel yang cukup homogen dan adanya oksida logam yang terdoping pada permukaan titania.

Gambar 4 memperlihatkan foto SEM dari nanopartikel $\mathrm{TiO}_{2}-\mathrm{CoFe}_{2} \mathrm{O}_{4}$ dengan konsentrasi ion dopan 0,01 yang dikalsinasi pada temperatur $500{ }^{\circ} \mathrm{C}$ dengan variasi pelarut. Dengan adanya variasi pelarut, maka dapat diketahui pelarut yang cocok digunakan untuk sintesis nanopartikel $\mathrm{TiO}_{2}-\mathrm{CoFe}_{2} \mathrm{O}_{4}$. Hal ini dapat diamati dari kehomogenan permukaan nanopartikel $\mathrm{TiO}_{2}-\mathrm{MFe}_{2} \mathrm{O}_{4}$ pada foto SEM dengan perbesaran 40.000 kali. Dari ketiga gambar tersebut dapat diamati bahwa nanopartikel $\mathrm{TiO}_{2}-\mathrm{CoFe}_{2} \mathrm{O}_{4}$ yang disintesis dengan menggunakan pelarut 1-propanol memperlihatkan permukaan yang lebih homogen dan merata dibandingkan dengan menggunakan pelarut etanol dan isopropanol. Hal ini mengindikasikan bahwa pelarut 1propanol merupakan pelarut yang paling cocok digunakan dalam pembuatan nanopartikel $\mathrm{TiO}_{2}-\mathrm{CoFe}_{2} \mathrm{O}_{4}$ dibandingkan pelarut etanol dan isopropanol.

Untuk memperoleh informasi tentang unsurunsur yang terdapat dalam nanopartikel $\mathrm{TiO}_{2}$ $\mathrm{CoFe}_{2} \mathrm{O}_{4}$ dilakukan analisis menggunakan alat Energy Dispersive $X$-ray (EDX). Dari analisis EDX akan dapat diketahui persen massa unsurunsur yang terdapat dalam nanopartikel $\mathrm{TiO}_{2}$ $\mathrm{CoFe}_{2} \mathrm{O}_{4}$.

Dari hasil analisis EDX nanopartikel $\mathrm{TiO}_{2}$ $\mathrm{CoFe}_{2} \mathrm{O}_{4}$ (Gambar 5) diperoleh kandungan $\mathrm{O}$ $39,33 \%$, Ti 57,59\%, Fe 1,60\%, dan Co 1,48\%. Data tersebut membuktikan bahwa 
pendopingan $\mathrm{Fe}$ dan $\mathrm{Co}$ pada $\mathrm{TiO}_{2}$ telah berhasil dilakukan. Persentase atom $\mathrm{Fe}$ dan $\mathrm{Co}$ yang kecil dibandingkan dengan atom $\mathrm{O}$ dan
Ti disebabkan karena konsentrasi ion dopan yang digunakan pada saat pendopingan juga kecil.

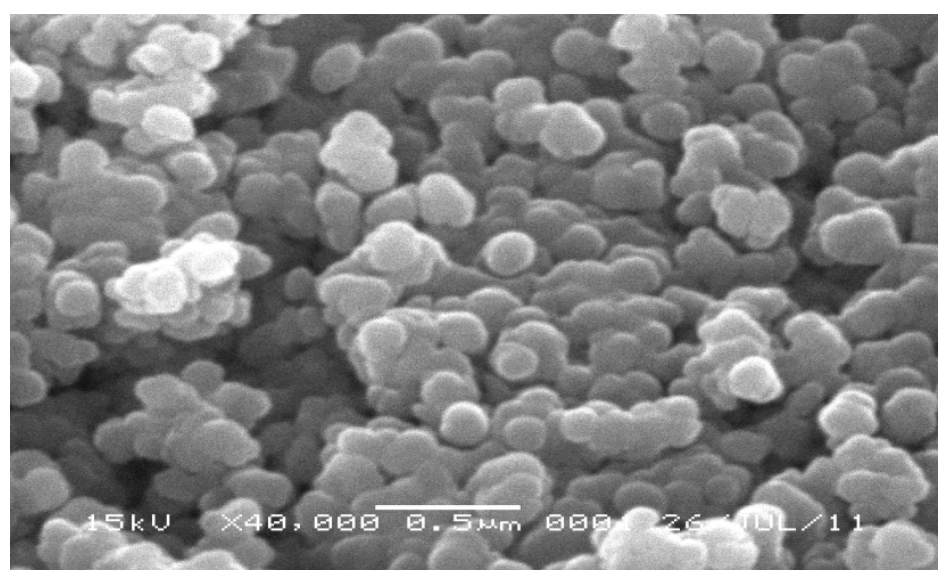

Gambar 3. Foto SEM dari nanopartikel $\mathrm{TiO}_{2}-\mathrm{CoFe}_{2} \mathrm{O}_{4}$

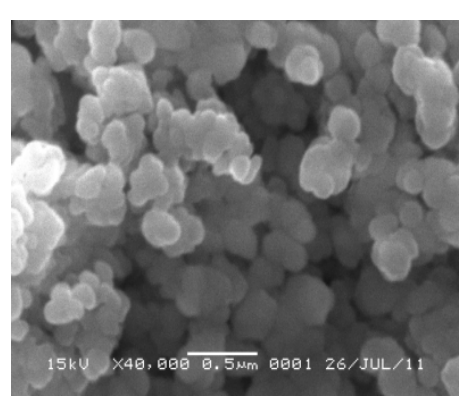

[a]

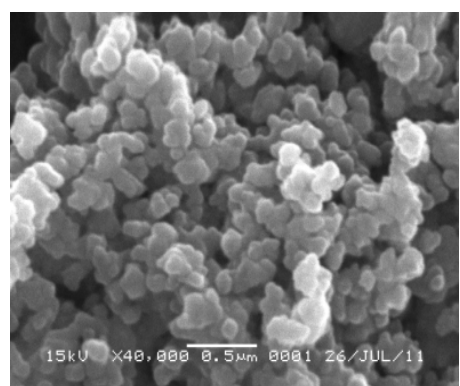

[b]

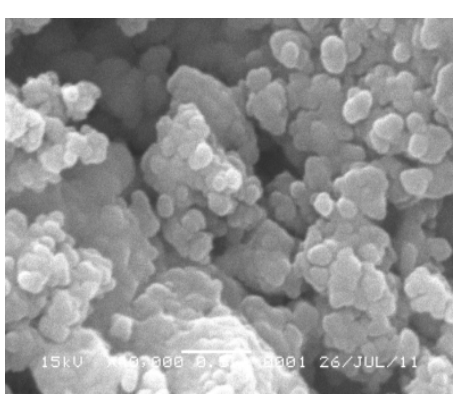

[c]

Gambar 4. Foto SEM perbesaran 40.000 kali dari nanopartikel $\mathrm{TiO}_{2}-\mathrm{CoFe}_{2} \mathrm{O}_{4}$ dengan variasi pelarut ; [a] pelarut etanol [b] pelarut1-propanol [c] pelarut isopropanol 


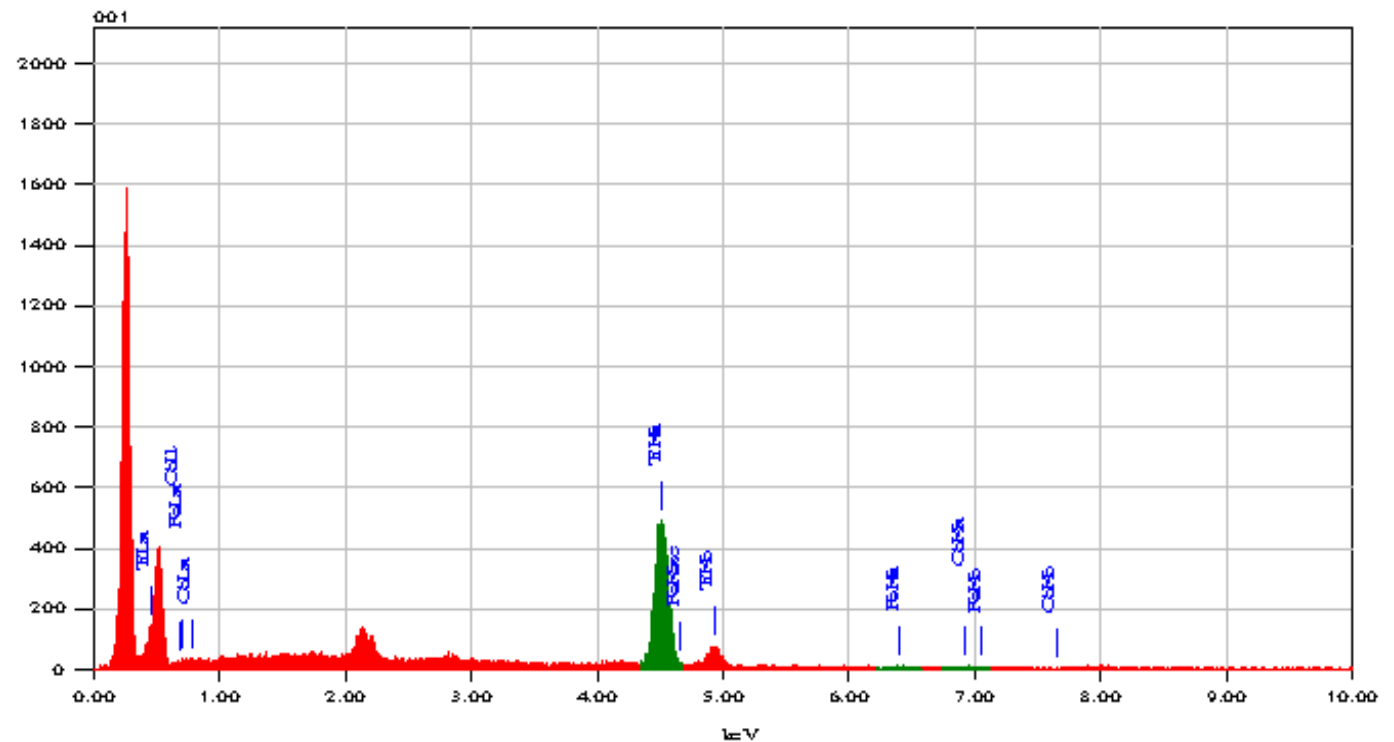

Gambar 5. Analisis EDX dari nanopartikel $\mathrm{TiO}_{2}-\mathrm{CoFe}_{2} \mathrm{O}_{4}$ yang dikalsinasi pada temperatur 500 ${ }^{\circ} \mathrm{C}$ dengan konsentrasi ion dopan 0,01 .

\section{Vibrating Sample Magnetometer (VSM)}

Pendopingan $\mathrm{TiO}_{2}$ dengan oksida logam menghasilkan nanopartikel yang memiliki sifat magnet dimana dengan adanya sifat magnet ini akan lebih mempermudah dalam mendaur ulang fotokatalis setelah digunakan pada proses fotokatalitik. Untuk mengetahui sifat magnet dari nanopartikel, dilakukan analisis menggunakan alat Vibrating Sample Magnetometer (VSM Oxford VSM 1.2 T). Dari kurva histeresis dapat diketahui sifat magnet dari nanopartikel yang disintesis.
Dari kurva histerisis VSM pada Gambar 6 terlihat nilai magnetic saturation (Ms) atau tingkat kejenuhan magnetisasi tertinggi dari nanopartikel $\mathrm{TiO}_{2}-\mathrm{CoFe}_{2} \mathrm{O}_{4}$ pada $0,128 \mathrm{emu} / \mathrm{g}$ dicapai pada kuat medan $0,9914 \mathrm{~T}$ dan titik terendah pada $-0,128 \mathrm{emu} / \mathrm{g}$ pada kuat medan $0,9911 \mathrm{~T}$, dengan nilai coercive $-0,0302$ sampai $0,0197 \mathrm{~T}$ dan nilai remanent 0,0123 $\mathrm{emu} / \mathrm{g}$. Dari data-data tersebut dapat disimpulkan bahwa sampel $\mathrm{TiO}_{2}-\mathrm{CoFe}_{2} \mathrm{O}_{4}$ bersifat paramagnetik. Dengan adanya sifat magnetik ini diharapkan material fotokatalis tersebut dapat dipisahkan dan didaur ulang untuk penggunaan selanjutnya.

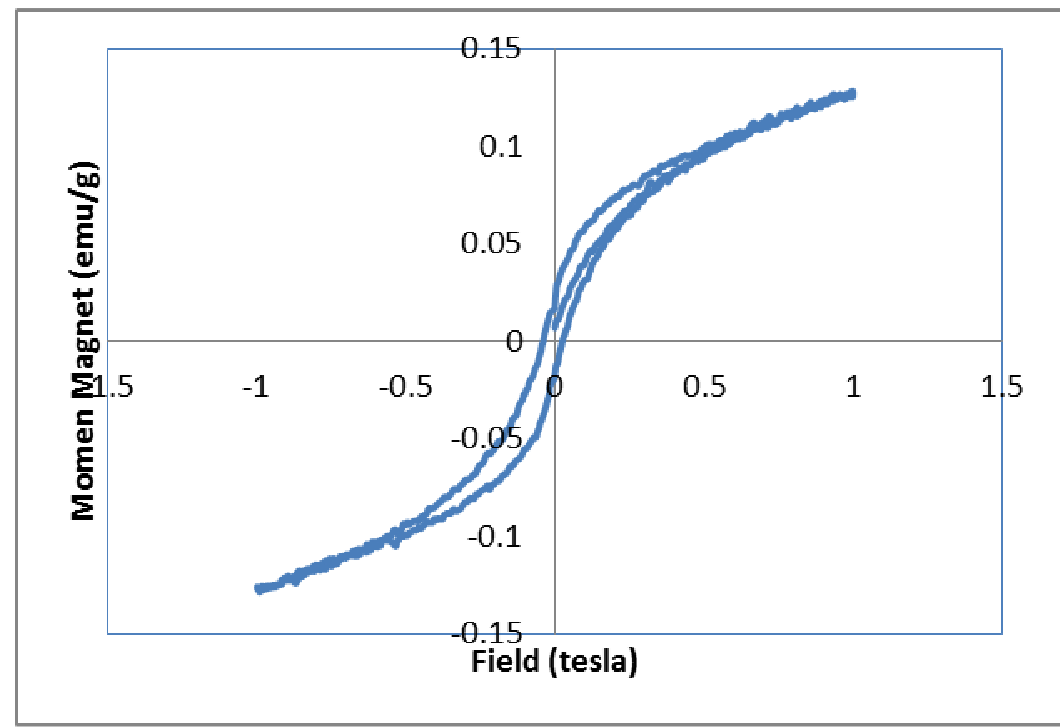

Gambar 6. Sifat magnetik dari nanopartikel $\mathrm{TiO}_{2}-\mathrm{CoFe}_{2} \mathrm{O}_{4}$ yang dikalsinasi pada temperatur $500{ }^{\circ} \mathrm{C}$ 
Uji Aktifitas Fotokatalitik Nanopartikel $\mathrm{TiO}_{2}-\mathrm{CoFe}_{2} \mathrm{O}_{4}$

Gambar 7 memperlihatkan hasil uji aktifitas fotokatalitik $\mathrm{TiO}_{2}-\mathrm{CoFe}_{2} \mathrm{O}_{4}$ dengan konsentrasi ion dopan 0,01 terhadap degradasi senyawa rodamin B dengan variasi waktu penyinaran 1,2 dan 3 jam menggunakan cahaya matahari. Dari grafik hubungan lama penyinaran dan absorban dapat dilihat bahwa nanopartikel $\mathrm{TiO}_{2}-\mathrm{CoFe}_{2} \mathrm{O}_{4}$ yang dikalsinasi pada temperatur $500{ }^{\circ} \mathrm{C}$ memiliki aktifitas fotokatalitik yang lebih baik dibanding yang lain karena memiliki kemampuan mendegradasi senyawa rhodamin B sampai sebesar $82 \%$ lebih tinggi dibanding yang lain. Besarnya persen degradasi dari nanopartikel $\mathrm{TiO}_{2}-\mathrm{CoFe}_{2} \mathrm{O}_{4}$ yang dikalsinasi pada temperatur $500{ }^{\circ} \mathrm{C}$ disebabkan karena memiliki struktur anatase dengan persentase yang cukup besar, sedangkan pada temperatur 550 dan 600 ${ }^{\circ} \mathrm{C}$, struktur rutil pada nanopartikel $\mathrm{TiO}_{2}$ $\mathrm{CoFe}_{2} \mathrm{O}_{4}$ sudah mulai terbentuk sehingga menyebabkan kemampuan nanopartikel dalam mendegradasi senyawa rhodamin B menjadi berkurang.

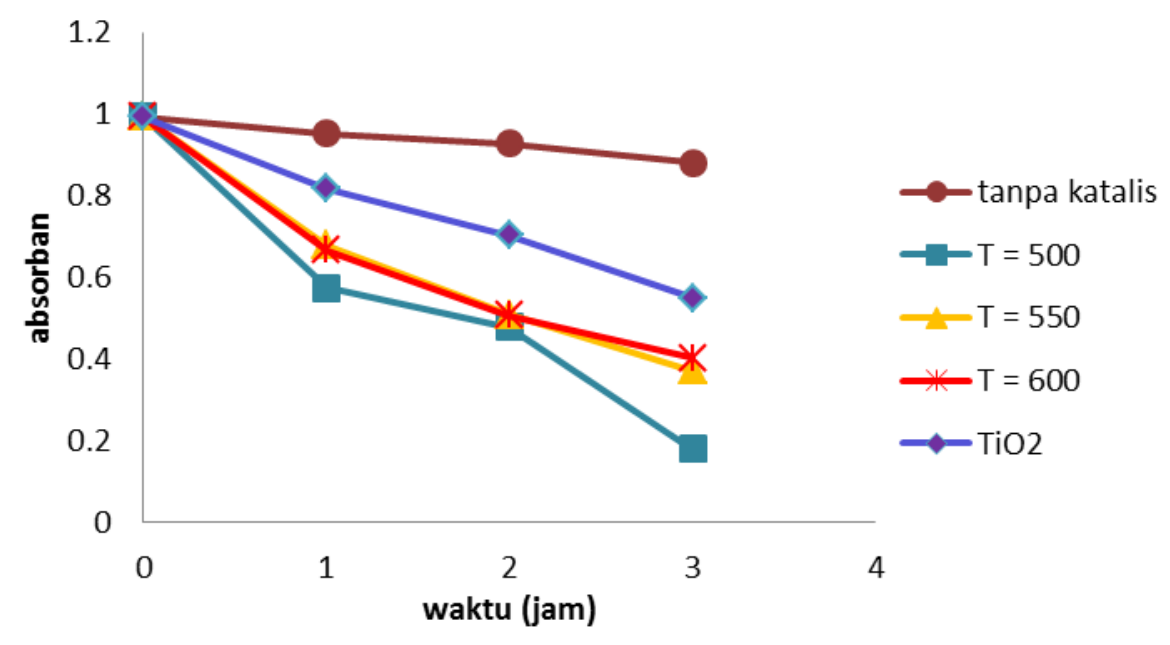

Gambar 7. Aktifitas fotokatalitik $\mathrm{TiO}_{2}-\mathrm{CoFe}_{2} \mathrm{O}_{4}$ dalam mendegradasi senyawa rhodamin $\mathrm{B}$ di bawah sinar matahari selama 3 jam

\section{KESIMPULAN}

Nanopatikel magnetik $\mathrm{TiO}_{2}-\mathrm{CoFe}_{2} \mathrm{O}_{4}$ telah disintesis menggunakan garam logam nitrat dan titanium isopropoksida sebagai material awal. Dari pola XRD dapat dilihat terbentuknya nanopartikel $\mathrm{TiO}_{2}-\mathrm{CoFe}_{2} \mathrm{O}_{4}$ berdasarkan munculnya puncak $\mathrm{TiO}_{2}$ anatase pada sudut $2 \theta: 25.3^{\circ}$ dan puncak $\mathrm{CoFe}_{2} \mathrm{O}_{4}$ pada sudut $2 \theta: 35.5^{\circ}$. Nanopartikel $\mathrm{TiO}_{2-}$ $\mathrm{CoFe}_{2} \mathrm{O}_{4}$ memiliki aktifitas fotokatalitik pada daerah sinar tampak dengan persen degradasi mencapai $82 \%$. Sifat magnetik dari partikel ini memberi kemungkinan partikel dapat didaur ulang setelah digunakankan untuk proses fotokatalis dalam air.

\section{DAFTAR KEPUSTAKAAN}

1. XU Shihong, SHANGGUAN Wenfeng, YUAN Jian, CHEN Mingxia and SHI Jianwei, Preparation and Photocatalityc Properties of Magnetically Separable $\mathrm{TiO}_{2}$ Supported on Nickle Ferrite, Chin. J. Chem. Eng., 15(2) 190-195 (2007).

2. A. Mikrajuddin, Khairurrijal dan $\mathrm{H}$. Mahfudz, Pendekatan Baru Penjernihan Air Limbah : Berbasis Nanomaterial dan Zero Energy, Berita Penelitian ITB (2009).

3. Ulman's, Encyclopedia of Industrial Chemistry, A 20, VCH, Germany, 271-272 (1992).

4. S.S. Sesha, Jeremi Wade and Elias K. Stefanakos, Synthesis and characterization of Photocatalytic $\quad \mathrm{TiO}_{2}-\mathrm{ZnFe}_{2} \mathrm{O}_{4}$ 
nanoparticles, Journal of Nanomaterials, article ID 45712, 1-4 (2006).

5. M. Anpo, Applications of titanium oxide photocatalysts and unique second generation $\mathrm{TiO}_{2}$ photocatalysts able to operate under visible light irradiation for the reduction of environmental toxins on a global scale, Studies in Surface Science and Catalysis, 130 A, 157-166 (2000).

6. M. Anpo, Applications of $\mathrm{TiO}_{2}$ photocatalyst to better our environment, Protecting the Environment, 75-88 (1998).

7. W. Chengyu, S. Huamei, T. Ying, Y. Tongsuo, and Z. Guowub, Properties and morphology of $\mathrm{CdS}$ compounded $\mathrm{TiO}_{2}$ visible-light photocatalytic nanofilms coated on glass surface, Separation and Purification Technology, 32, no. 1-3, 357362 (2003).

8. J. Premkuma, Development of superhydrophilicity on nitrogen-doped $\mathrm{TiO}_{2}$ thin film surface by photoelectrochemical method under visible light, Chemistry of Materials, 16, no. 21, 3980-3981 (2004).
9. S. Mozia, M. Toaszewska, B. Kosowska, B. Brzmil, A. W. Morawski, and K. Kalucki, Decomposition of nonionic surfactant on a nitrogen-doped photocatalyst under visiblelight irradiation, Applied Catalysis B: Environmental, 55, no. 3, 195-200 (2005).

10. U. Schubert, N. Husing, Synthesis of Inorganic Material, Germany : Wiley VHC (2000).

11. Z. Baoping, Z. Jinlong and C. Feng, Preparation and characterization of magnetic $\mathrm{TiO}_{2} / \mathrm{ZnFe}_{2} \mathrm{O}_{4}$, Res. Chem. Interned., 34, No. 4, 375-380 (2008). 